\title{
Impact of External Communication on Internal Brand Management Outcomes Using Employees as a Second Audience: A Comparative Analysis of Manufacturing and Service Sectors of Pakistan
}

\author{
Syed Hussain Raza Rizvi ${ }^{1} \&$ Danish Ahmed Siddiqui \\ ${ }^{1}$ Research Scholar, Karachi University Business School, University of Karachi, Pakistan \\ ${ }^{2}$ Associate Professor, Karachi University Business School, University of Karachi, Pakistan \\ Correspondence: Syed Hussain Raza Rizvi, Research Scholar, Karachi University Business School, University of \\ Karachi, Pakistan.
}

Received: February 15, 2019

Accepted: April 1, $2019 \quad$ Online Published: April 4, 2019

doi:10.11114/bms.v5i2.4062

URL: https://doi.org/10.11114/bms.v5i2.4062

\begin{abstract}
This study investigated the effect of External Brand Communications on internal brand management practices using brand commitment and brand understanding as factors determining the phenomenon and subsequently analyzing the effect of both internal and external factors on brand citizenship behavior. A sample size of 300 respondents was selected from manufacturing and service oriented companies and the effects were analyzed using Structural Equation Modeling. It was found that there is significant and positive influence of brand understanding in determination of brand citizenship behavior and reflected mediating role of external communication congruence. Furthermore, it has also found that internal brand management practices are more evident in case of manufacturing firm i.e. a reputed Biscuits Manufacturing Company as compare to financial firm i.e. a renowned Private Limited Bank. It reveals necessity of work required in case of Private Limited Bank to work on external communication practices and integrate it with internal brand management practices to increase its role in determination of employee behavior and their role in propagating brand image as second audience.
\end{abstract}

Keywords: external communication congruence (ECC), brand understanding (BU), brand commitment (BC), brand citizenship behavior (BCB)

\section{Introduction}

\subsection{Background}

Employees are recognized as important stakeholders in organizational structure and have committed with responsibility to represent brand attribute, directly or indirectly, to ultimate customers in the form of brand attributes with realization of brand commitments (Burmann \& Zeplin, 2005). It has identified as an important determinant of customer satisfaction toward brand offers. It also results in trust and development of stronger brand customer relationship development (Ballester et al, 2003). There is a significant role of employees in brand development and management as internal stakeholder (Piehler et al, 2015). There is a series of studies that have investigated role of employees in development of internal brand management practices to induce brand practices in organizational structure affectively, behaviorally and cognitively at human resource (Harris \& Chernatony, 2001).

Internal brand management practices are target oriented with positive outcomes on brand image. Employee input their brand understanding in organizational practices and processes to ensure brand commitment and contribute in development of brand behavior (Burmann et al, 2009). In addition, managerial intellectual practices have found significant input in development of quality service and manufacturing outcomes (Baumgarth \& Schmidt, 2010). Furthermore, it has also found that employee contributes with brand oriented leadership styles and its resultant impact targeted customer segment of the organization (King \& Grace, 2012).

Similarly, brand management practices have also got integrated with human resource practices and resulted in the form of brand oriented human resource management practice (Punjaisri \& Wilson, 2011). Another study also revealed that employees have significant role to develop internal atmosphere toward brand and contribute in development of brand 
image that not only determine its level of understand but also its reflection toward customers (Burmann \& Zeplin, 2005). Although external communication i.e. advertising has significantly used to build brand awareness among employees and communicate brand attributes to ultimate customers while on the other hand, customer or public relationships are significantly used to represent brand identity and fulfill commitment to external stakeholders i.e. customers. It has both positive and negative impact on development of brand image.

External communication has although found significant impact on external stakeholders i.e. investors, customers, regulatory authorities. It has revealed through studies that external communication has found a sense of worth among employees and their positive attitude toward development of brand citizenship behavior (Ind, 2001; Bergstrom et al. 2002; de Chernatony et al. 2003; Piehler, Schade \& Burmann, 2017). In addition, it has also found significant impact on determination of employee's behavior toward. In external communication, employees have recognized as second audience (Morhart et al, 2009)It also helps in development of employee's motivation, brand identification, brand awarded attitude and standardized behavior (Burmann \& Zeplin, 2005).

\subsection{Problem Statement}

Studies conducted on internal brand management practices has not significantly found to address external communication as an effective managerial attribute to determine its outcome on employees as brand representative (Henkel et al, 2007). It reflects the essence of research studies required to address the impact of external communication in determination of internal brand management outcomes to reflect role of employees as second audience to express brand presence among competent market offerings. It has further required to extract the scope of employee specific internal brand management outcomes to address its positive impact on develop employee behavior as brand ambassadors (Hughes, 2013). It also needs to reveal employee's behavior toward brand commitment and brand specific behavior (Piehler et al. 2016). It has also found that there is a significant gap among employee to understand implications of external communication in determination of internal brand management outcomes to aggregate employee attitude toward brand figures (Xiong et al, 2013).

"To investigate the impact of external communication on internal brand management outcomes using employees as a second audience in service and manufacturing sector in Pakistan."

\subsection{Gap Analysis}

There were few recent studies done on the subject area to determine role of external communication in determination of internal brand management practices and its impact on employee to serve as secondary audience to propagate brand image (Thomson et al, 1999, Ind, 2001; Bergstrom et al. 2002; de Chernatony et al. 2003). Among them, Bergstrom et al. (2002) found insignificant impact of internal brand commitment on firm's brand citizenship behavior. It has revealed through investigation of different components of external communication to determine its influence on employee's behavior. It has revealed that clearance of message, awareness to core aspects of brand and brand representation has found significant role in determination of employee's behavior. Punjaisri et al, (2008) also explored individual influence of brand understanding, brand commitment in determination of brand citizenship behavior, but it doesn't account for the inter-correlation between brand understanding and brand commitment. It has revealed that usage of brand language has an important role in determination of brand image. Furthermore, collective commitment to brand from senior management has also found influential role in determination of employee's attitude and behavior. However, (Henkel et al, 2007) revealed positive inter-correlation among brand understanding and brand commitment and their impact on firm's brand citizenship behavior but identified with lack of inclusion of external communication convergence in determination of brand citizenship behavior. Furthermore (Burmann \& Zeplin, 2005) also found deterministic power of external communication convergence on firm's brand citizenship behavior but the evidence was not highly significance and they ignored internal effects. This study has conducted on firms operating in USA using primary research approach. In addition, Chernatony et al. (2003) study also revealed a significant impact of external communication on brand citizenship behavior. The above mentioned studies either investigated external or internal factors' effects on brand citizenship. Hence they lack the combined approach. Piehler, Schade \& Burmann (2017) revealed through their work that there is positive correlation of branch citizenship behavior to brand commitment and to brand endowment while insignificant impact on brand development as case in text book using focus group sessions. They also found positive correlation of brand understanding to behavior relevance and brand knowledge. However this study was limited to a developed country. In developed countries, audience are educated with academic background. For a developing country, these demographic characteristic could have different impact on the results, as awareness to basic knowledge has found significant influence on employee's attitude and serve as supportive demographic factors (Henkel, Tomczak, Heitmann \& Herrmann,2007). Moreover, another study was done on manufacturing industry, but found with low significance level of external communication in determination of internal brand management practices. Hence their effect in different industry is still left unexplored. Both manufacturing and service industry have different 
commitment and understanding levels and affected differently by external brand communications. Therefore, bases on the above mentioned findings, this study investigated implications of brand understanding, brand commitment and external communication congruence over brand citizenship behavior. Furthermore, it also investigates correlation between external communication congruence on brand understanding and commitment along with impact of brand understanding over brand commitment based on recently conducted in case of developed country (Piehler, Schade \& Burmann, 2017). This study reflects its value addition with its investigation in case of developing country. In addition, this study also performs with comparative assessment of two firms in Pakistan to understand practical differences.

\subsection{Objective \& Significance}

The objective of this research study is to investigate association of internal brand management practices and external communication on employee. This also encloses to determine the scope of internal brand management practices and its reflection on employees as second audience (Henkel et al, 2007). Furthermore, we also investigate the impact of external communication in determination of internal brand management outcomes to reflect role of employees as second audience to express brand presence among competent market offerings.

It to interlink external communication to internal brand management practices along with mediating effect of brand communication and understanding on internal brand management practices and its implication to employee in perspective of their role as brand ambassador in case of developing country focusing on Pakistan. In addition, comparative assessment of manufacturing and services sector firm is conducted to understand cross industry implications.

\subsection{Outline of the Study}

This study started with introductory section focusing on problem statement, description to study background along with objectives and significance to research study. Section 2, proceed with brief review of current literature along with identification of research gaps. Section 3 develop a conceptual framework along with definition of hypotheses. Section 4, followed with research methodology with description of nature and type of study, targeted population, sampling technique and sample size. Section 5 explained research model and statistical technique. Finally, findings are summarized and recommendations are designed based on findings in section 6. In addition, limitations are defined and future prospect of studies are highlighted.

\section{Literature Review}

\subsection{Internal Brand Management Outcomes}

Internal brand management practices have investigated with the development of comprehensive models to address its outcomes and its implications on managerial practices instead of focusing on front line employees (Thomson et al, 1999, Ind, 2001; Bergstrom et al. 2002; de Chernatony et al. 2003). Burmann \& Zeplin (2005) used these foundations to develop more comprehensive explanation to internal brand management and its implication on employees of an organization without studying expressive role of external communication on it. Punjaisri et al (2008) further enriched it with qualitative explanation. Baumgarth \& Schmidt (2010) added with quantitative measures and validated using on primary research techniques.

Piehler et al (2015) validated the definition of internal brand management practices to describe its aspects in cognitive, affective and behavioral manner to employees of an organization but only cross sectional in nature. (Vallaster \& Chernatony, 2005) further explained that employee level internal brand management practices result in better understanding to brand, fulfillment of commitment and development of behavior of employee toward brand but does not involved with intermediary role of brand understanding and commitment in its explanation. Henkel et al (2007) used and explained brand supporting attitude to explain employee's behavior toward a brand as a response factor in term of internal brand management practices but does not addressed brand commitment within the study. Furthermore, (Punjaisri \& Wilson 2011) found brand performance as response factor toward brand management practices. (King et al. 2012; hndorf \& Diamantopoulos, 2014; Piehler et al. 2016) provided with variable such as employer brand equity behavior, brand building attitude and brand citizenship responsiveness with significant impact of brand building attitude and citizenship responsiveness in determination of equity behavior of employees.

In contrast to unidimensional perspective of brand citizenship behavior, (Piehler, 2018) found multi-dimensional perspective, not only focused customers but also influential on employees, has significant potential to strengthen brand presence among different stakeholder they found helpful in development of brand compliance i.e. brand specific principles and guidelines along with brand level endorsement to reflect brand's advocacy (Nyadzayo et al, 2016). Brand citizenship behavior has also found helpful to improve brand development process not only among customers but also among employees to increase brand identity (King \& Grace, 2012). It has further revealed through study that there is a significant impact of institutional level commitment on organizational level citizenship behavior as well as brand 
citizenship behavior (King and Grace 2010).

\subsubsection{Brand Commitment}

Brand commitment is used as another employee specific internal brand management outcomes. Brand commitment results in emotional attachment to brand among employees (Punjaisri \& Wilson, 2011). A sequence of studies revealed that there is a significant impact of brand commitment on brand citizenship behavior (Burmann et al, 2009). It has also found that employees have found positive contribution in development of brand presence due to their emotional attachment with development of their behavior toward the brand (Piehler et al, 2016).

Khalid \& Tariq (2015) further explained through a study that there is significant role of branding processing recruitment process to understand interest of potential candidate about brand. Raman (2012) explained through a study that internal brand management has successfully revealed function and operational aspects of external communication to reflect symbiotic association of external and internal stakeholders in Pakistan. It has also helped to deliver brand promise and its reflection among employee to contribute their input in development of brand culture among ultimate customer. Furthermore, it has also inputted to build internal brand alignment in organization. Ahmad \& Khan (2014) also supported with investigation that internal brand management has given integration of marketing practices to human resource practices in Pakistan. It has also integrated internal brand management to brand orientation with its ultimate positive impact on internal brand equity.

H1: There is a significant impact of brand commitment on employee's brand citizenship behavior.

\subsubsection{Brand Understanding}

Internal brand management practices have found significant contribution in determination of brand understanding among employee (Xiong et al. 2013). Brand understanding resulted in development of brand knowledge among employees (Dean et al. 2016). Terglav et al. (2016) has explained brand understanding as level of information endowment among employees. Baumgarth \& schmidt (2010) investigated one-dimensional aspect of brand understanding among employees. It has later criticized and evident with multi-dimensional aspects to understand and capture comprehensive brand specific information that has actually hold by employees (Lohndorf \& Diamantopoulos 2014). Terglav et al. (2016) further revealed that there is a significant scope of multi-dimensional aspect of brand related information in developing employee's level of knowledge (Piehler 2018). Multi-dimensional aspect of brand conceptualization includes brand relevancy that actually address employee attention toward brand and its essence to determine organizational success. In addition, brand relevance has also found supportive to input with brand realization and employee's contribution in brand development process.

H3: There is a significant impact of brand understanding on employee's brand citizenship behavior.

(King and Grace 2010) further revealed that brand understanding has significant role to interrelate brand commitment to brand citizenship behavior. It has found that deficiency of brand related knowledge among employee results in lack of employees' behavior to reflect their brand related behavior and often evident with ambiguities. It has found through study that ambiguities often evident with negative correlation to employee commitment level to organizations (Meyer et al. 2002). Eatough et al. (2011) expressed that an increased level of brand understanding evident with clarity of role among employee and their responsibility toward brand. It has found that there is a positive correlation of brand understanding to brand commitment (King 2010). It has also found that brand understanding also results in development of positive brand specific employees' behavior (King \& Grace, 2010). A sequence of studies revealed that there is a positive impact of brand understanding toward employees' level of brand commitment (King et al. 2012; Piehler et al, 2016). It has also found that there is a positive impact of brand understanding toward employees' brand citizenship behavior (Terglav et al. 2016; Lohndorf \& Topoulos, 2014)

$\mathrm{H} 2$ : There is a significant impact of brand understanding on employee's brand commitment.

\subsection{External Communication}

Internal brand management practices have found significant association to advertising and service and manufacturing marketing activities (Thomson et al, 1999).

Internal brand specific attributes have also resulted in alignment of external communication to actual worth of brand among employees and targeted market segment (Ind, 2001).

An exaggerated perception of product among employee results in development of negative image of product or service and manufacturing among employees along with its negative propagation to ultimate targeted market (Chernatony et al. 2006).

External communication has also contributed with correspondence of incorporation of internal and external stakeholder to harmonize understanding with its assurance in organizational goals (Miles et al, 2011). Mahnert \& Torres (2007) 
further revealed the importance of internal and external communication in development of brand appearance with reflection of its actual values to both employees and customers. It has also found that there is a significant impact of external communication on internal brand management outcomes in organizational perspective. It has also found that absence of external communication results in lack of congruence of employees in terms of external communication and deficiency to develop sufficient level of brand understanding among employee along with customers.

Another study revealed that insufficient level or deficiency of external communication evident with confusion and conflict of roles among employees to propagate brand messages and promises properly (Mahnert \& Torres, 2007).

H4: There is a significant impact of external communication congruence on employees about brand understanding.

Branding understanding has also found an influence on brand commitment along with influence of external communication on brand commitment (Gilly \& Wolfinbarger, 1992). An over-emphasized level of promises made by a brand results in an increase in level of frustration among employee to fulfill hence results in decline in level of trust on brand (Miles \& Mangold, 2004). It has observed with reduction in level of identification and commitment of the brand among employees and customers (Wolfinbarger \& Gilly, 1991). In contrast, a realization among employees about ethnicity of external message has found positive impact employees' level of absorption and results in development of positive response with level of pride and identification of brand (Gilly \& Wolfinbarger, 1998). This results in an increase in employees' level of commitment toward brand as second audience.

Another study also revealed that commitment of an organization in terms of external communication results in decline in employees' role congruence and an increase in level of conflicts for employees (Miles \& Mangold, 2004). (Meyer et al. 2002) also found a negative correlation between role conflicts of employees with their level of commitment in case of exaggerated level of external communication

Gilly \& Wolfinbarger (1998) further revealed that inappropriate level of advertising and promises results in reduction in level of employees' identification of brand with varying level of commitment. Wolfinbarger \& Gilly (2005) further added that there is a negative correlation of exaggerated level of trust toward brand identification. An increase in level of employees' confusion that has found significant threat to their perception toward the organization and lack in employees' level of fulfillment of integrity. (Miles \& Mangold, 2004) found abnormal level of external communication usually found inappropriate toward employees and results in perceive response of decision makers toward employees with lack of trust and mistreated.

H5: There is a significant impact of external communication congruence on employees' brand commitment.

It has reflected through social learning theory that people usually learn about new behaviors from behaviors of people in their social network or surrounding hence their behaviors are consequences of their atmosphere (Bandura 1977). External communication has capacity to address behavior of employees and its potential consequences on employees' behavior with propagating role models in an organization for employees. A desired depiction of employee behavior through external communication results in its positive level of acceptance among customers with positive impact on brand. This also helps employees to get engage in accepted role model to contribute in brand development process (Wolfinbarger \& Gilly, 1991). In contrast, a failure to correlate exaggerated promises that are beyond potential of employees results in development of confusion and conflicts (Eatough et al. 2011). Furthermore, conflict that develops due to weaknesses in external communication congruence has found negative correlation to brand citizenship behavior (Podsakoff et al. 1996).

H6: There is a significant impact of external communication congruence on employees' brand citizenship behavior.

\section{Conceptual Framework}

\subsection{Brand Commitment}

Brand commitment is an important element of internal brand management outcomes and determine influence on employee's brand citizenship behavior. It reflects emotional attachment of employee to brand (Wilson \& Punjaisri, 2011). King \& Grace (2012) extracted three different components of organizational commitment. In addition, brand commitment has also found a unidirectional construct (Chernatony \& Vallaster, 2005). Brand commitment has found positive influence on employee's brand citizenship behavior (Zeplin \& Burmann, 2005). Another study also revealed deterministic behavior of brand commitment on brand citizenship behavior in positive manner (Meyer et al. 2002).

\subsection{Brand Understanding}

An increased level of brand understanding evident with clarity of role among employee and their responsibility toward brand citizenship behavior. It has found that there is a positive correlation of brand understanding to brand citizenship behavior (King 2010). It has also found that brand understanding also results in development of positive brand specific employees' behavior (King \& Grace, 2010). A sequence of studies revealed that there is a positive impact of brand 
understanding toward employees' level of brand citizenship behavior. (Piehler et al, 2016). External communication has found significant scope in incorporation of internal and external stakeholder within organizational structure to harmonize understanding with its assurance in development of brand commitment (Miles et al, 2011).

\subsection{External Communication Congruence}

Torres \& Mahnert (2007) revealed the importance of internal and external communication in development of brand understanding with its positive influence on both employees and customers. It has also found that there is a significant constructive impact of external communication on internal brand understanding and management outcomes from organizational perspective (Mitchell, 2002). It has also found that absence of external communication results in lack of congruence of employees in terms of brand understanding and deficiency to develop sufficient level of brand commitment among employee along with customers (Podsakoff et al. 1996).

\subsection{Brand Citizenship Behavior}

Brand citizenship behavior has found with significant implication of brand understanding, external communication congruence and brand commitment in its determination (Hughes, 2013). Brand commitment is an important element of internal brand management outcomes and determine influence on employee's brand citizenship behavior (Henkel, Tomczak, Heitmann \& Herrmann, 2007). A sequence of studies revealed that there is a positive impact of brand understanding toward employees' level of brand citizenship behavior. (Piehler et al, 2016).

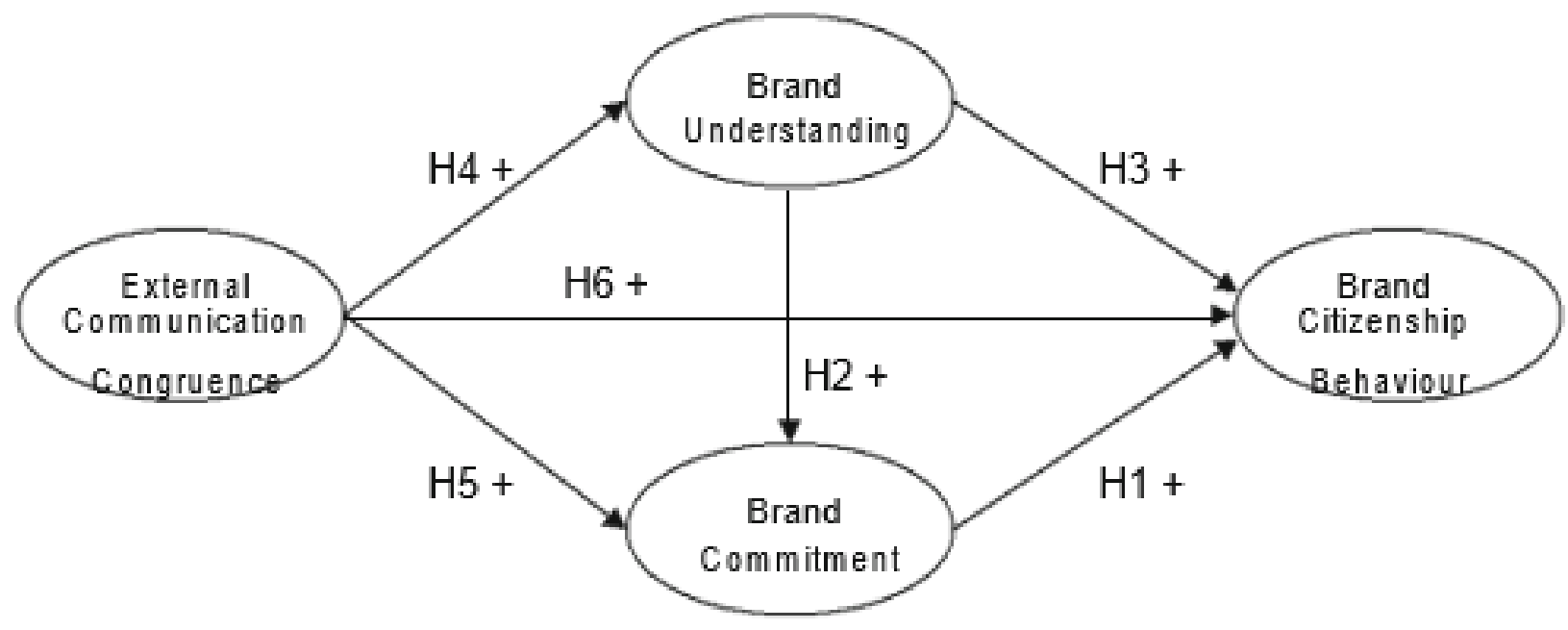

Figure 1. Conceptual Framework (Source: Piehler, Schade \& Burmann, 2017)

\section{Industry Analysis}

Manufacturing sector has its own characteristics as compare to service sector hence reveals different outcomes of external communication congruence, brand understanding and commitment in determination of brand citizenship behavior.

\subsection{Services}

Service sector has relatively found with low employee retention rate as compare to manufacturing sector due to relatively higher level of each option to switch and adjustment to work environment therefore brand related practices in service sector has found more volatile and significant concern toward employee retention. It has found that services sector relatively observed with higher level of marketing expenditures as compare to manufacturing varies for both industries. Service industry is more dependent on employee interaction to promote brand presence within market place and its success level. In addition, it has also found that in service sector employees are more subjected to training programs to get more award about brand and its attributes. It has found that variation in brand understanding due to variation in external communication congruence results in significant influence on brand citizenship behavior. Marginal impact of brand understanding on brand commitment is relatively more influential as compare to manufacturing sector. Similarly, external communication has found significant role in determination of brand understanding, commitment and citizenship behavior.

\subsection{Manufacturing}

Manufacturing sector has found with relatively consistent level of practices and higher level of product life cycle as 
compare to service sector hence observed with relatively consistent level of external communication strategy with its lapse for employees to observed and apply in their work practices. Employees in manufacturing sector has found relatively higher tenure of experience as compare to service sector hence more educated to brand and its different attributes therefore found with significant scope of external communication in determination of brand commitment, understanding and citizenship behavior. Furthermore, it has also found supportive to determine influence of external communication over brand commitment and understanding.

\section{Research Methodology}

\subsection{Research Design}

This research study has adopted explanatory approach to determine the impact of brand commitment, understanding and external communication congruence in explaining internal brand management practices using brand citizenship behavior as proxy to it. Furthermore, primary data has employed through questionnaire as no secondary source available to get required information. In addition, questionnaire has used as data collection instrument with selection of two firms i.e. Biscuits Manufacturing Company and a Private Limited Bank as targeted population. A sample size of 300 was selected. Google doc form has used to design questionnaire and get required information. Total of 165 Reponses are collected from Private Limited Bank and 135 from Biscuits Manufacturing Company.

\subsection{Survey Measure}

This research study makes use of Likert scale in construction of questionnaire along with its from base work done in past by studies (Dyne et al, 1994; Burmann et al, 2009; and Morhart et al, 2009). In addition, brand commitment related elements were derived from work of Meyer \& Allen using affective commitment scale (Meyer \& Allen, 1997). Furthermore, brand understanding construct was used from (Thomson et al, 1999; Burmann et al, 2009). In addition, external communication related questions were adopted from (Wolfinbarger \& Gilly, 2005). These constructed were used to collect information from employees of two different organizations as done in previous studies (King \& Grace, 2010; Burmann et al. 2009; Piehler et al. 2016).

Table 1. Survey Measures

\begin{tabular}{lllll}
\hline S.No. & Researchers & Study & Measure Used \\
\hline 1 & $\begin{array}{l}\text { Van Dyne, L., Cummings, L. L, } \\
\text { \& McLean Parks, J. (1995) }\end{array}$ & $\begin{array}{l}\text { Extra role behaviors: In pursuit of construct and } \\
\text { definitional clarity. }\end{array}$ & $\begin{array}{l}\text { Likert Scale based } \\
\text { questionnaire }\end{array}$ \\
\hline 2 & $\begin{array}{l}\text { Burmann C., Zeplin S. \& RILEY } \\
\text { N., (2008) }\end{array}$ & $\begin{array}{l}\text { Key determinants of internal brand management } \\
\text { success: An exploratory empirical analysis }\end{array}$ & $\begin{array}{l}\text { Likert Scale based } \\
\text { questionnaire }\end{array}$ \\
\hline \multirow{2}{*}{$\begin{array}{l}\text { Morhart, F. M., Herzog, W., \& } \\
\text { Tomczak, T. (2009) }\end{array}$} & $\begin{array}{l}\text { Brand-specific leadership: Turning employees } \\
\text { into brand } \\
\text { Champions }\end{array}$ & $\begin{array}{l}\text { Likert Scale based } \\
\text { questionnaire }\end{array}$ \\
\hline 4 & Jaros S. (2007) & Meyer and Allen Model of Organizational & Likert Scale based \\
Commitment: Measurement Issues & questionnaire \\
\hline 5 & Thomson et al, (1999) & The Role of Internal Branding in Nonprofit Brand \\
Management: An Empirical Investigation & $\begin{array}{l}\text { Likert Scale based } \\
\text { questionnaire }\end{array}$ \\
\hline
\end{tabular}

\subsection{Data Collection \& Sample Profile}

The questionnaire was uploaded on Google online form to collect information from respondents from two selected organizations i.e. Biscuits Manufacturing Company and a Private Limited Bank based on self-completed approach of data collection. Management of respective organizations were engaged and e-form was sent to employees of these organizations, to fill it at their ease. Through managers, it was already informed to the employees of organization to participate in this survey with attention. Furthermore, privacy of respondents has kept in confidence to ensure to protect their identity. There were around 400 e-mails sent to employees of both organizations but collected with around 300 responses hence response rate was around 75 percent. Data was than extracted in excel format and cleaned for analysis purpose. Demographics were revealed that around 14 percent of respondents were female and 86 percent male. 45 percent response is from Biscuits Manufacturing Company while 55 percent response is from Private Limited Bank.

\subsection{Descriptive Statistics}

First questions "I really feel my company's brand related problems are my own" revealed that mean value Biscuits Manufacturing Company is 3.263 with standard deviation of 1.202 and sample size of 135 . In contrast, means for Private Limited Bank is 3.652 with standard deviation of 1.108 and sample size of 165 . Furthermore, mean value for overall 
sample is 2.946 with standard deviation 1.186. It has clearly reflected that means value although is in favor of Biscuits Manufacturing Company but standard deviation is higher in case of Private Limited Bank It reveals that brand ownership is higher in case of Biscuits Manufacturing Company as compare to Private Limited Bank.

Family attachment to brand is higher in case of Private Limited Bank as compare to Biscuits Manufacturing Company with means values 3.874 and 3.3000 respectively. The value of standard deviation is also lower in case of Private Limited Bank as compare to Biscuits Manufacturing Company. Similarly, the value of mean for internal emotions toward company's brand has higher mean value for Private Limited Bank as compare to Biscuits Manufacturing Company with mean values of 3.748 and 3.287 respectively. In addition, standard deviation values for Biscuits Manufacturing Company and Private Limited Bank are 1.199 and 1.042 respectively. It reveals that internal emotions are relatively more for employees of Private Limited Bank as compare to Biscuits Manufacturing Company.

In addition, identification of company's brand as self-identity has also higher mean value for Private Limited Bank as compare Biscuits Manufacturing Company with mean values of 3.830 and 3.287 respectively along with standard deviation values of 1.011 and 1.212 respectively. It reveals that employees of Private Limited Bank have also good sense of brand as identify as compare to Biscuits Manufacturing Company. It has also found through leading question i.e. I have a strong sense of belonging to my company' brand, there is relatively better sense in case of employees of Private Limited Bank as compare to Biscuits Manufacturing Company with mean values of 3.719 and 3.273 respectively hence reflect brand level of internal brand management in case of Private Limited Bank as compare to Biscuits Manufacturing Company.

This study also revealed that sense of strength of brand with its importance to organizational success is more expressive in case of Private Limited Bank as compare to Biscuits Manufacturing Company with mean value of 3.719 and 3.273 respectively. It reveals that employees of Private Limited Bank are more sensitive to brand strength for organizational success as compare to Biscuits Manufacturing Company. It has also found through next questions that correlation of band success to organizational success is more elaborative for Private Limited Bank as compare to Biscuits Manufacturing Company with mean values of 4.067 and 3.453 respectively. Furthermore, standard deviation value is also lower for former as compare later hence justify results in favor of Private Limited Bank to support the evidence with practices among employees to favor ownership of assets to the brand representation. Study also revealed through question on presence of brand to rebound commitment and dedication to targeted customers with mean value of 3.993 and 3.350 respectively. The standard deviation value also found 0.877 for former and 1.265 for later.

Question on brand's understanding to customers is higher for Private Limited Bank as compare to Biscuits Manufacturing Company with mean values of 3.911 and 3.240 respectively. Furthermore, standard deviation values are 0.877 and 1.265 for Private Limited Bank and Biscuits Manufacturing Company respectively. It reveals that customer understand is more in case of Private Limited Bank as compare to Biscuits Manufacturing Company next question, other people would characterize me as someone who follows brand-related rules and instructions, revealed that employees are relatively more compliant to brand practices in case of Private Limited Bank as compare to Biscuits Manufacturing Company with means values of 4.037 and 3.290. In addition, standard deviation values are also found 0.876 and 1.368 for Private Limited Bank and Biscuits Manufacturing Company respectively.

It has also found through question i.e. other people would characterize me as someone who pays attention that his personal appearance is in line with brand's appearance, there is also significant influence in case of Private Limited Bank as compare to Biscuits Manufacturing Company with mean values of 3.807 and 3.227 respectively hence revealed that personal appearance is more toward brand appearance for Private Limited Bank as compare to Biscuits Manufacturing Company. In next question it has found that employee's behavior in line as standard for brand adequate behavior with mean value of 4.104 and 3.267 for Private Limited Bank and Biscuits Manufacturing Company respectively. In addition, standard deviation values are 0.900 and 1.357 for Private Limited Bank and Biscuits Manufacturing Company respectively. It has clearly explained alignment of action of employees toward the brand.

It has also found in upcoming question i.e. products and services of brand are actually as good as portrayed in the external brand communication, revealed importance of external communication to internal brand management and found with mean value of 3.993 and 3.390 for Private Limited Bank and Biscuits Manufacturing Company respectively. In addition, standard deviation values for Private Limited Bank and Biscuits Manufacturing Company are 1.026 and 1.226 respectively. It has also found through next question that value portrayed in external communication to represent lived values in brand with mean value of 3.993 and 3.353 respectively. It expressively represents importance of brand livingness among employees of Private Limited Bank as compare to Biscuits Manufacturing Company comparatively. It has found through next question that mean value for Private Limited Bank is 3.941 and 3.397 for Biscuits Manufacturing Company for question that there are no inconsistencies at all between internal and external brand communication at brand. It revealed that employees are more informed in case of Private Limited Bank as compare to 
Biscuits Manufacturing Company.

Table 2. Descriptive Statistics

\begin{tabular}{|c|c|c|c|c|c|c|c|c|}
\hline & \multicolumn{2}{|c|}{$\begin{array}{l}\text { Model } \\
\text { Overall }\end{array}$} & \multicolumn{2}{|c|}{ Model I } & $\begin{array}{l}\text { Biscuits } \\
\text { ompany }\end{array}$ & \multicolumn{2}{|c|}{$\begin{array}{l}\text { Model II } \\
\text { Limited Bank }\end{array}$} & \multirow{2}{*}{$\begin{array}{l}\text { Private } \\
\text { St.Dev. }\end{array}$} \\
\hline & Mean & St.Dev. & $\mathrm{N}$ & Mean & St.Dev. & $\mathrm{N}$ & Mean & \\
\hline $\begin{array}{l}\text { I really feel my company's brand related } \\
\text { problems are my own }\end{array}$ & 3.263 & 1.202 & 135 & 3.652 & 1.108 & 165 & 2.946 & .186 \\
\hline $\begin{array}{l}\text { I am like as a part of the family of my } \\
\text { company's brand }\end{array}$ & 3.300 & 1.192 & 135 & 3.874 & 0.981 & 165 & 2.830 & 1.146 \\
\hline $\begin{array}{l}\text { I have internal emotions towards my } \\
\text { company's brand }\end{array}$ & 3.273 & 1.199 & 135 & 3.748 & 1.042 & 165 & 2.885 & 1.181 \\
\hline $\begin{array}{l}\text { I feel my company's brand as my identity to } \\
\text { firm }\end{array}$ & 3.287 & 1.212 & 135 & 3.830 & 1.011 & 165 & 2.842 & 1.184 \\
\hline $\begin{array}{l}\text { I have a strong sense of belonging to my } \\
\text { company' brand }\end{array}$ & 3.273 & 1.218 & 135 & 3.719 & 1.034 & 165 & 2.909 & 1.239 \\
\hline $\begin{array}{l}\text { A strong brand is of great importance for our } \\
\text { organization's success }\end{array}$ & 3.393 & 1.465 & 135 & 4.089 & 1.011 & 165 & 2.824 & 1.534 \\
\hline $\begin{array}{l}\text { Our brand is an important asset of our } \\
\text { organization }\end{array}$ & 3.453 & 1.452 & 135 & 4.067 & 0.986 & 165 & 2.952 & 1.577 \\
\hline $\begin{array}{l}\text { Brand success is directly related to our } \\
\text { organization's success }\end{array}$ & 3.347 & 1.293 & 135 & 3.844 & 1.105 & 165 & 2.939 & 1.296 \\
\hline $\begin{array}{l}\text { Our brand reflect of commitment and } \\
\text { dedication to targeted customers }\end{array}$ & 3.350 & 1.265 & 135 & 3.993 & 0.877 & 165 & 2.824 & 1.292 \\
\hline $\begin{array}{l}\text { Our brand has an understanding to its } \\
\text { customers }\end{array}$ & 3.240 & 1.350 & 135 & 3.911 & 1.040 & 165 & 2.691 & 1.328 \\
\hline $\begin{array}{l}\text { Other people would characterize me as } \\
\text { someone who follows brand-related rules } \\
\text { and instructions }\end{array}$ & 3.290 & 1.368 & 135 & 4.037 & 0.876 & 165 & 2.679 & 1.397 \\
\hline $\begin{array}{l}\text { Other people would characterize me as } \\
\text { someone who avoids damaging brand }\end{array}$ & 3.420 & 1.239 & 135 & 4.052 & 0.925 & 165 & 2.903 & 1.226 \\
\hline $\begin{array}{l}\text { Other people would characterize me as } \\
\text { someone who pays attention that his personal } \\
\text { appearance is in line with brand's appearance }\end{array}$ & 3.227 & 1.337 & 135 & 3.807 & 1.116 & 165 & 2.752 & 1.318 \\
\hline $\begin{array}{l}\text { Other people would characterize me as } \\
\text { someone who acts in line with the standards } \\
\text { for brand-adequate behavior of brand }\end{array}$ & 3.267 & 1.357 & 135 & 4.104 & 0.900 & 165 & 2.582 & 1.283 \\
\hline $\begin{array}{l}\text { Other people would recognize me from my } \\
\text { brand }\end{array}$ & 3.377 & 1.357 & 135 & 4.104 & 0.925 & 165 & 2.782 & 1.366 \\
\hline $\begin{array}{l}\text { Products and services of brand are actually as } \\
\text { good as portrayed in the external brand } \\
\text { communication }\end{array}$ & 3.390 & 1.226 & 135 & 3.993 & 1.026 & 165 & 2.897 & 1.156 \\
\hline $\begin{array}{l}\text { The values portrayed in the external brand } \\
\text { communication of represent actually lived } \\
\text { values at brand }\end{array}$ & 3.353 & 1.330 & 135 & 3.993 & 0.918 & 165 & 2.830 & 1.386 \\
\hline $\begin{array}{l}\text { There are no inconsistencies at all between } \\
\text { internal and external brand communication } \\
\text { at brand }\end{array}$ & 3.397 & 1.341 & 135 & 3.941 & 1.035 & 165 & 2.952 & 1.400 \\
\hline $\begin{array}{l}\text { I feel well informed about the brand goals of } \\
\text { brand }\end{array}$ & 3.363 & 1.328 & 135 & 3.837 & 1.059 & 165 & 2.976 & 1.401 \\
\hline $\begin{array}{l}\text { I feel well informed about the brand promise } \\
\text { of brand }\end{array}$ & 3.423 & 1.226 & 135 & 3.904 & 0.976 & 165 & 3.030 & 1.271 \\
\hline
\end{tabular}

\section{Results}

\subsection{Model I (Overall)}

\subsubsection{Convergent \& Discriminate Validity Test}

CFA has applied on collected data to test convergent and discriminate validity of results. It has found that value of KMO and Bartlett's Test is significant at 5 percent level of significance with significance value of 0.00 hence supported the evidences in favor of convergent validity. 
Table 3. KMO \& Bartlett's Test for Convergent Validity - Model I

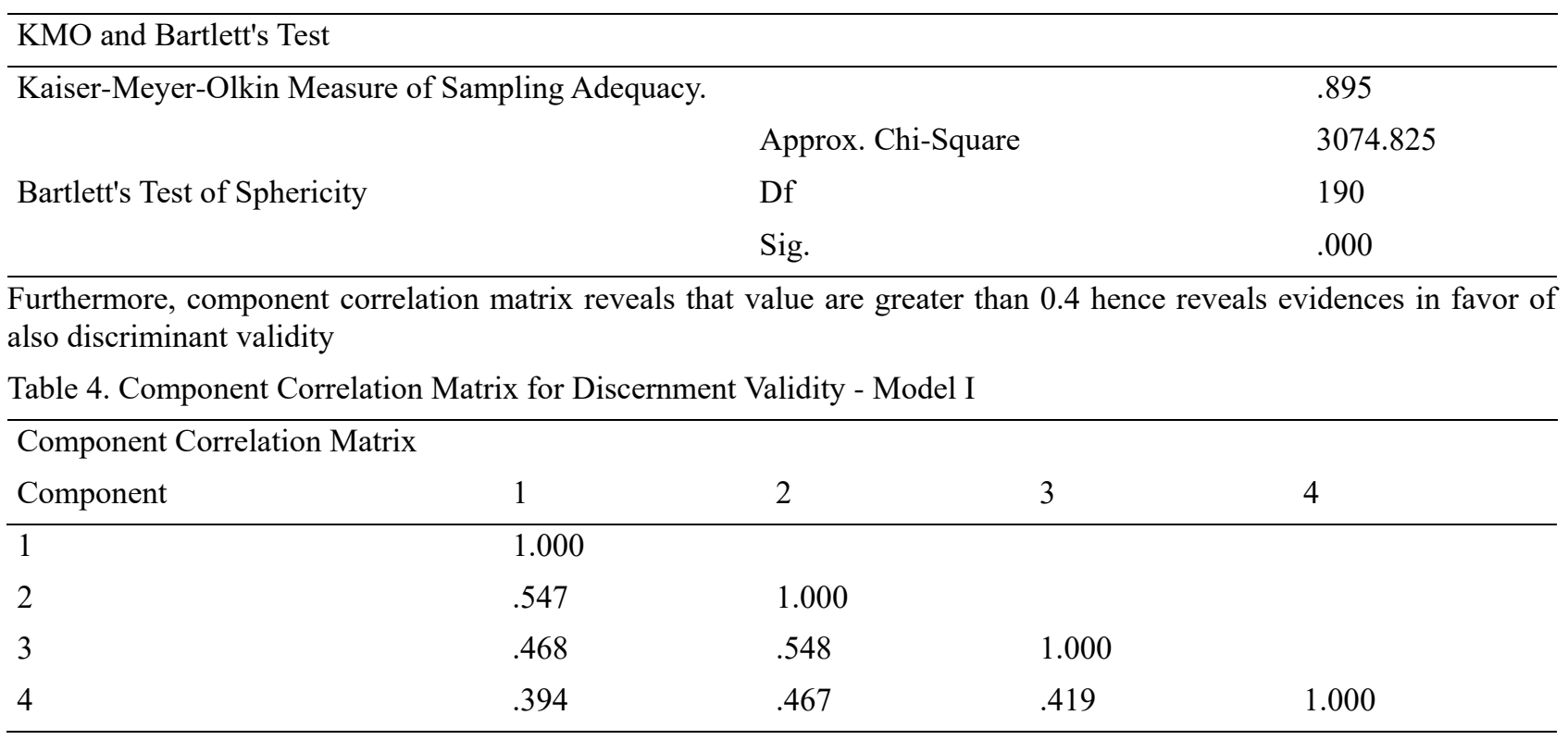

Extraction Method: Principal Component Analysis.

Rotation Method: Promax with Kaiser Normalization.

6.1.2 Reliability Test

Furthermore, the value of Cronbach's Alpha is also greater than 0.6 hence also support the evidence in favor of reliability of collected responses during current study.

Table 5. Cronbach's Alpha for Reliability Test

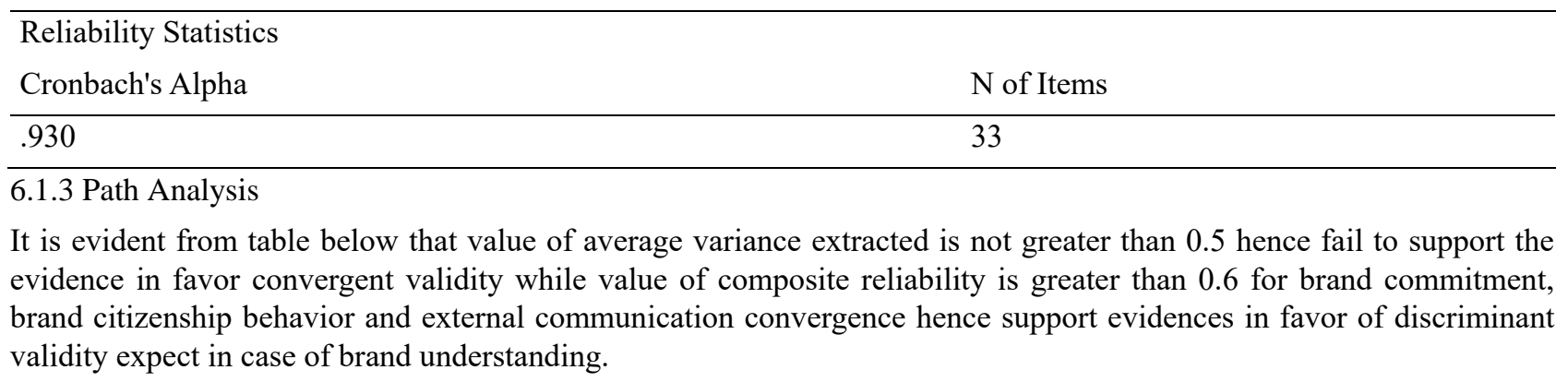


Table 6. Factor Loading, AVE \& Composite Reliability - Model 1

\begin{tabular}{|c|c|c|c|c|c|c|}
\hline Variables & \multicolumn{4}{|l|}{ Items } & $\begin{array}{l}\text { Factor } \\
\text { Loading }\end{array}$ & $\begin{array}{l}\text { Error } \\
\text { Term }\end{array}$ \\
\hline \multirow{5}{*}{ Brand Commitment } & \multicolumn{4}{|c|}{ I really feel my company's brand related problems are my own } & 0.826 & 0.317 \\
\hline & \multicolumn{4}{|c|}{ I am like as a part of the family of my company's brand } & 0.657 & 0.568 \\
\hline & \multicolumn{4}{|c|}{ I have internal emotions towards my company's brand } & 0.723 & 0.476 \\
\hline & \multicolumn{4}{|c|}{ I feel my company's brand as my identity to firm } & 0.809 & 0.345 \\
\hline & \multicolumn{4}{|c|}{ I have a strong sense of belonging to my company' brand } & 0.289 & 0.916 \\
\hline \multirow{5}{*}{ Brand Understanding } & \multicolumn{4}{|c|}{ A strong brand is of great importance for our organization's success } & 0.772 & 0.403 \\
\hline & \multicolumn{4}{|c|}{ Our brand is an important asset of our organization } & 0.756 & 0.428 \\
\hline & \multicolumn{4}{|c|}{ Brand success is directly related to our organization's success } & 0.213 & 0.954 \\
\hline & \multicolumn{4}{|c|}{ Our brand reflect of commitment and dedication to targeted customers } & 0.248 & 0.938 \\
\hline & \multicolumn{4}{|c|}{ Our brand has an understanding to its customers } & 0.103 & 0.989 \\
\hline \multirow{5}{*}{$\begin{array}{l}\text { Brand } \\
\text { Behavior }\end{array}$} & \multicolumn{4}{|c|}{$\begin{array}{l}\text { Other people would characterize me as someone who follows brand-related } \\
\text { rules and instructions }\end{array}$} & 0.766 & 0.412 \\
\hline & \multicolumn{4}{|c|}{$\begin{array}{l}\text { Other people would characterize me as someone who avoids damaging } \\
\text { brand }\end{array}$} & 0.798 & 0.362 \\
\hline & \multicolumn{4}{|c|}{$\begin{array}{l}\text { Other people would characterize me as someone who pays attention that his } \\
\text { personal appearance is in line with brand's appearance }\end{array}$} & 0.185 & 0.965 \\
\hline & \multicolumn{4}{|c|}{$\begin{array}{l}\text { Other people would characterize me as someone who acts in line with the } \\
\text { standards for brand-adequate behavior of brand }\end{array}$} & 0.333 & 0.888 \\
\hline & \multicolumn{4}{|c|}{ Other people would recognize me from my brand } & 0.345 & 0.88 \\
\hline \multirow{5}{*}{$\begin{array}{l}\text { External } \\
\text { Communication } \\
\text { Convergence }\end{array}$} & \multicolumn{4}{|c|}{$\begin{array}{l}\text { Products and services of brand are actually as good as portrayed in the } \\
\text { external brand communication }\end{array}$} & 0.225 & 0.949 \\
\hline & \multicolumn{4}{|c|}{$\begin{array}{l}\text { The values portrayed in the external brand communication of represent } \\
\text { actually lived values at brand }\end{array}$} & 0.211 & 0.955 \\
\hline & \multicolumn{4}{|c|}{$\begin{array}{l}\text { There are no inconsistencies at all between internal and external brand } \\
\text { communication at brand }\end{array}$} & 0.809 & 0.343 \\
\hline & \multicolumn{4}{|c|}{ I feel well informed about the brand goals of brand } & 0.805 & 0.351 \\
\hline & \multicolumn{4}{|l|}{ ECC5 } & 0.684 & 0.531 \\
\hline \multicolumn{2}{|l|}{ Variables } & AVE & Composite Reliability & \multicolumn{2}{|c|}{ Cronbach's Alpha } & \\
\hline \multicolumn{2}{|l|}{ Brand Commitment } & 0.475 & 0.806 & 0.753 & & \\
\hline \multicolumn{2}{|l|}{ Brand Understanding } & 0.257 & 0.541 & 0.814 & & \\
\hline \multicolumn{2}{|c|}{ Brand Citizenship Behavior } & 0.298 & 0.627 & 0.772 & & \\
\hline \multicolumn{2}{|c|}{ External Communication Convergence } & 0.3734 & 0.705 & 0.786 & & \\
\hline
\end{tabular}

\subsubsection{Model Fit}

Model 1 has applied on overall data collected to constructed hypothesis. At first instance it has revealed that overall model is significant at 5 percent level of significance with significance value of 0.000 and also Chi-square value is too high to support the acceptance of the model as mentioned below. 
Table 7. Model Fit - Model 1

Model Fit

Chi-square

948.613

Degrees of freedom

164

Probability level

0.000

\subsubsection{Coefficient Matrix}

It is evident from coefficient matrix table that there is a significant impact of external communication convergence over brand understanding with significance value of 0.000 and the value of coefficient is 1.111. Similarly, brand understanding has also found significant impact on brand commitment with significance value of 0.000 i.e. less than 5 and coefficient value is 0.336 . Furthermore, brand understanding has also found significant impact on brand citizenship behavior with significance value of less than 5 percent i.e. 0.000 and having coefficient value of 0.709 while there is no significant impact of external communication convergence over brand commitment, external communication convergence over brand citizenship behavior and brand commitment over brand citizenship behavior.

Table 8. Coefficient Matrix - Model 1

\begin{tabular}{|c|c|c|c|c|}
\hline Coefficient Matrix & Estimate & S.E. & C.R. & $\mathrm{P}$ \\
\hline Brand Understanding <--- External Communication Convergence & 1.111 & 0.167 & 6.644 & 0.000 \\
\hline Brand Commitment <--- External Communication Convergence & 0.038 & 0.07 & 0.546 & 0.585 \\
\hline Brand commitment $<---$ Brand Understanding & 0.336 & 0.064 & 5.237 & 0.000 \\
\hline Brand Citizenship Behavior <--- Brand Understanding & 0.709 & 0.113 & 6.262 & 0.000 \\
\hline $\begin{array}{l}\text { Brand Citizenship Behavior <--- External Communication } \\
\text { Convergence }\end{array}$ & 0.106 & 0.107 & 0.989 & 0.323 \\
\hline Brand Citizenship Behavior <--- Brand Commitment & -0.093 & 0.143 & -0.647 & 0.517 \\
\hline
\end{tabular}

6.2 Model II - Biscuits Manufacturing Company

\subsubsection{Convergent \& Discriminate Validity Test}

CFA has applied on collected data for Biscuits Manufacturing Company to test convergent and discriminate validity of results. It has found that value of KMO and Bartlett's Test is significant at 5 percent level of significance with significance value of 0.00 hence supported the evidences in favor of convergent validity.

Table 9. KMO \& Bartlett's Test for Convergent Validity

\begin{tabular}{|c|c|c|c|c|}
\hline \multicolumn{4}{|l|}{ KMO and Bartlett's Test } & \\
\hline \multicolumn{4}{|c|}{ Kaiser-Meyer-Olkin Measure of Sampling Adequacy. } & .887 \\
\hline \multirow{3}{*}{ Bartlett's Test of Sphericity } & \multicolumn{3}{|c|}{ Approx. Chi-Square } & 1439.151 \\
\hline & & Df & & 190 \\
\hline & & Sig. & & .000 \\
\hline \multirow{2}{*}{\multicolumn{5}{|c|}{$\begin{array}{l}\text { Furthermore, component score covariance matrix reveals that value } \\
\text { support of discriminant validity } \\
\text { Table 10. Component Correlation Matrix for Discernment Validity }\end{array}$}} \\
\hline & & & & \\
\hline \multicolumn{5}{|c|}{ Component Score Covariance Matrix } \\
\hline Component & 1 & 2 & 3 & 4 \\
\hline 1 & 1.000 & & & \\
\hline 2 & 0.000 & 1.000 & & \\
\hline 3 & 0.000 & 0.000 & 1.000 & \\
\hline 4 & 0.000 & 0.000 & 0.000 & 1.000 \\
\hline
\end{tabular}

Extraction Method: Principal Component Analysis.

Rotation Method: Verimax with Kaiser Normalization. 


\subsubsection{Convergent \& Discriminate Validity Test}

Furthermore, the value of Cronbach's Alpha is also greater than 0.6 hence also support the evidence in favor of reliability of collected responses during current study for model II.

Table 11. Cronbach's Alpha for Reliability Test

\begin{tabular}{ll}
\hline $\begin{array}{l}\text { Reliability Statistics } \\
\text { Cronbach's Alpha }\end{array}$ & N of Items \\
\hline .940 & 33 \\
\hline 6.2 .3 Path Analysis &
\end{tabular}

The table mentioned below reveals that only AVE for brand commitment fulfill the requirement of convergence as value is greater than 0.5 while rest of the information has found with lack of capacity to fulfill the requirement of convergence. In addition, composite reliability has similar trend it is only favor evidence in support of brand commitment to fulfill decrement validity while not for brand understanding, brand citizenship behavior and external communication convergence as values are less than 0.6.

Table 12. Factor Loading, AVE \& Composite Reliability - Model II

\begin{tabular}{|c|c|c|c|}
\hline Variables & Items & $\begin{array}{l}\text { Factor } \\
\text { Loading }\end{array}$ & $\begin{array}{l}\text { Error } \\
\text { Term }\end{array}$ \\
\hline \multirow{5}{*}{$\begin{array}{l}\text { Brand } \\
\text { Commitm } \\
\text { ent }\end{array}$} & I really feel my company's brand related problems are my own & 0.7409 & 0.451 \\
\hline & I am like as a part of the family of my company's brand & 0.843 & 0.2876 \\
\hline & I have internal emotions towards my company's brand & 0.7628 & 0.418 \\
\hline & I feel my company's brand as my identity to firm & 0.8223 & 0.3237 \\
\hline & I have a strong sense of belonging to my company' brand & 0.7311 & 0.4654 \\
\hline \multirow{5}{*}{$\begin{array}{l}\text { Brand } \\
\text { Understan } \\
\text { ding }\end{array}$} & A strong brand is of great importance for our organization's success & 0.2782 & 0.9225 \\
\hline & Our brand is an important asset of our organization & 0.2689 & 0.9276 \\
\hline & Brand success is directly related to our organization's success & -0.006 & 0.9999 \\
\hline & Our brand reflect of commitment and dedication to targeted customers & 0.6096 & 0.6283 \\
\hline & Our brand has an understanding to its customers & 0.4552 & 0.7927 \\
\hline \multirow{5}{*}{$\begin{array}{l}\text { Brand } \\
\text { Citizenshi } \\
\text { p } \\
\text { Behavior }\end{array}$} & $\begin{array}{l}\text { Other people would characterize me as someone who follows brand-related rules and } \\
\text { instructions }\end{array}$ & 0.2111 & 0.9554 \\
\hline & Other people would characterize me as someone who avoids damaging brand & -0.0365 & 0.9986 \\
\hline & $\begin{array}{l}\text { Other people would characterize me as someone who pays attention that his personal } \\
\text { appearance is in line with brand's appearance }\end{array}$ & 0.3682 & 0.8644 \\
\hline & $\begin{array}{l}\text { Other people would characterize me as someone who acts in line with the standards for } \\
\text { brand-adequate behavior of brand }\end{array}$ & 0.221 & 0.9511 \\
\hline & Other people would recognize me from my brand & 0.2598 & 0.9324 \\
\hline \multirow{5}{*}{$\begin{array}{l}\text { External } \\
\text { Communi } \\
\text { cation } \\
\text { Converge } \\
\text { nce }\end{array}$} & $\begin{array}{l}\text { Products and services of brand are actually as good as portrayed in the external brand } \\
\text { communication }\end{array}$ & 0.233 & 0.9456 \\
\hline & $\begin{array}{l}\text { The values portrayed in the external brand communication of represent actually lived } \\
\text { values at brand }\end{array}$ & 0.0454 & 0.9979 \\
\hline & $\begin{array}{l}\text { There are no inconsistencies at all between internal and external brand communication } \\
\text { at brand }\end{array}$ & 0.2101 & 0.9558 \\
\hline & I feel well informed about the brand goals of brand & 0.1545 & 0.9761 \\
\hline & ECC5 I feel well informed about the brand promise of brand & 0.4204 & 0.8231 \\
\hline
\end{tabular}


Table 12. Continued

\begin{tabular}{llll}
\hline Variables & AVE & Composite Reliability & Cronbach's Alpha \\
\hline Brand Commitment & 0.6107 & 0.8866 & 0.894 \\
Brand Understanding & 0.1457 & 0.3764 & 0.813 \\
Brand Citizenship Behavior & 0.0595 & 0.1822 & 0.749 \\
External Communication Convergence & 0.0602 & 0.194 & 0.811 \\
\hline
\end{tabular}

6.2.4 Model Fit

Model II has run for Biscuits Manufacturing Company only. The information below, for model fitness, reveals that overall model is significant at 5 percent level of significance with significance value of 0.000 hence can proceed with further interpretation.

Table 13. Model Fit - Model II

\section{Model Fit}

Chi-square

Degrees of freedom

Probability level

\subsubsection{Coefficient Matrix}

Coefficient matrix table clearly reveals that there is a significant impact of external communication convergence over brand understanding with significance value of 0.001 and the value of coefficient is 1.013. Similarly, brand understanding has also found significant impact on brand commitment with significance value of 0.000 i.e. less than 5 and coefficient value is 0.77 . Furthermore, brand understanding has also found significant impact on brand citizenship behavior with significance value of 0.004 and coefficient value of 0.425 . In contrast, external communication convergence has found no significant on brand commitment and brand citizenship behavior. Similarly, brand commitment has also not found significant impact on brand citizenship behavior.

Table 14. Coefficient Matrix - Model II

\begin{tabular}{lllll}
\hline Coefficient Matrix & Estimate & S.E. & C.R. & P \\
\hline Brand Understanding <--- External Communication Convergence & 1.013 & 0.172 & 5.872 & 0.001 \\
Brand Commitment <--- External Communication Convergence & -0.076 & 0.238 & -0.319 & 0.749 \\
Brand commitment <--- Brand Understanding & 0.77 & 0.211 & 3.647 & 0.000 \\
Brand Citizenship Behavior <--- Brand Understanding & 0.425 & 0.149 & 2.859 & 0.004 \\
Brand Citizenship Behavior <--- External Communication & & & & \\
Convergence & 0.207 & 0.136 & 1.522 & 0.128 \\
Brand Citizenship Behavior <--- Brand Commitment & 0.013 & 0.073 & 0.178 & 0.859 \\
\hline
\end{tabular}

\subsection{Model III - Private Limited Bank}

\subsubsection{Convergent \& Discriminate Validity Test - Model III}

CFA has applied on collected data for Private Limited Bank to test convergent and discriminate validity of results. It has found that value of KMO and Bartlett's Test is significant at 5 percent level of significance with significance value of 0.00 hence supported the evidences in favor of convergent validity.

Table 15. KMO \& Bartlett's Test for Convergent Validity - Model III

\begin{tabular}{lll}
\hline KMO and Bartlett's Test & & \\
\hline Kaiser-Meyer-Olkin Measure of Sampling Adequacy. & & 0.684 \\
& Approx. Chi-Square & 1278.197 \\
Bartlett's Test of Sphericity & Df & 190 \\
& Sig. & 0.000 \\
\hline
\end{tabular}

$\overline{\text { Furthermore, component score covariance matrix reveals that value are less than } 0.4 \text { hence does not support evidence in }}$ support of discriminant validity 
Table 16. Component Correlation Matrix for Discernment Validity - Model III

\begin{tabular}{lllllll}
\hline $\begin{array}{l}\text { Component Score Covariance Matrix } \\
\text { Component }\end{array}$ & 1 & 2 & 3 & 4 & 5 & 6 \\
\hline 1 & 1.000 & & & & & \\
2 & 0.000 & 1.000 & & & & \\
3 & 0.000 & 0.000 & 1.000 & & & \\
4 & 0.000 & 0.000 & 0.000 & 1.000 & & \\
5 & 0.000 & 0.000 & 0.000 & 0.000 & 1.000 & \\
6 & 0.000 & 0.000 & 0.000 & 0.000 & 0.000 & 1.000 \\
7 & 0.000 & 0.000 & 0.000 & 0.000 & 0.000 & 0.000 \\
\hline
\end{tabular}

Extraction Method: Principal Component Analysis.

Rotation Method: Verimax with Kaiser Normalization.

\subsubsection{Reliability Test - Model III}

Furthermore, the value of Cronbach's Alpha is also greater than 0.6 hence also support the evidence in favor of reliability of collected responses during current study for model III.

Table 17. Cronbach's Alpha for Reliability Test - Model III

\begin{tabular}{ll}
\hline Reliability Statistics & N of Items \\
Cronbach's Alpha & 33 \\
\hline 741 &
\end{tabular}

\subsubsection{Path Analysis - Model III}

The table mentioned below, for model III, reveals that only AVE for brand commitment fulfill the requirement of convergence as value is greater than 0.5 while rest of the information has found with lack of capacity to fulfill the requirement of convergence. In addition, composite reliability has similar trend it is only favor evidence in support of brand commitment to fulfill decrement validity while not for brand understanding, brand citizenship behavior and external communication convergence as values are less than 0.6.

Table 18. Factor Loading, AVE \& Composite Reliability - Model III

\begin{tabular}{|c|c|c|c|}
\hline Variables & Items & $\begin{array}{l}\text { Factor } \\
\text { Loading }\end{array}$ & $\begin{array}{l}\text { Error } \\
\text { Term }\end{array}$ \\
\hline \multirow{5}{*}{ Brand Commitment } & I really feel my company's brand related problems are my own & 0.8308 & 0.3097 \\
\hline & I am like as a part of the family of my company's brand & 0.3486 & 0.8784 \\
\hline & I have internal emotions towards my company's brand & 0.7247 & 0.4747 \\
\hline & I feel my company's brand as my identity to firm & 0.7598 & 0.4226 \\
\hline & I have a strong sense of belonging to my company' brand & -0.06 & 0.9962 \\
\hline \multirow{5}{*}{ Brand Understanding } & A strong brand is of great importance for our organization's success & 0.8411 & 0.2923 \\
\hline & Our brand is an important asset of our organization & 0.8153 & 0.3352 \\
\hline & Brand success is directly related to our organization's success & -0.001 & 0.9999 \\
\hline & Our brand reflect of commitment and dedication to targeted customers & 0.0709 & 0.9949 \\
\hline & Our brand has an understanding to its customers & 0.0351 & 0.9987 \\
\hline \multirow{5}{*}{$\begin{array}{l}\text { Brand } \\
\text { Citizenship Behavior }\end{array}$} & $\begin{array}{l}\text { Other people would characterize me as someone who follows brand-related rules } \\
\text { and instructions }\end{array}$ & 0.7772 & 0.3959 \\
\hline & Other people would characterize me as someone who avoids damaging brand & 0.8172 & 0.3321 \\
\hline & $\begin{array}{l}\text { Other people would characterize me as someone who pays attention that his } \\
\text { personal appearance is in line with brand's appearance }\end{array}$ & -0.064 & 0.9958 \\
\hline & $\begin{array}{l}\text { Other people would characterize me as someone who acts in line with the standards } \\
\text { for brand-adequate behavior of brand }\end{array}$ & 0.117 & 0.9863 \\
\hline & Other people would recognize me from my brand & 0.1471 & 0.9783 \\
\hline \multirow{5}{*}{$\begin{array}{l}\text { External } \\
\text { Communication } \\
\text { Convergence }\end{array}$} & $\begin{array}{l}\text { Products and services of brand are actually as good as portrayed in the external } \\
\text { brand communication }\end{array}$ & 0.1884 & 0.9644 \\
\hline & $\begin{array}{l}\text { The values portrayed in the external brand communication of represent actually } \\
\text { lived values at brand }\end{array}$ & 0.0746 & 0.9944 \\
\hline & $\begin{array}{l}\text { There are no inconsistencies at all between internal and external brand } \\
\text { communication at brand }\end{array}$ & 0.0913 & 0.9916 \\
\hline & I feel well informed about the brand goals of brand & -0.0007 & 0.9999 \\
\hline & I feel well informed about the brand promise of brand & 0.1412 & 0.98 \\
\hline
\end{tabular}


Table 18. Continued

\begin{tabular}{llll}
\hline Variables & AVE & Composite Reliability & Cronbach's Alpha \\
\hline Brand Commitment & 0.5206 & 0.5441 & 0.605 \\
Brand Understanding & 0.3522 & 0.3441 & 0.565 \\
Brand Citizenship Behavior & 0.3587 & 0.318 & 0.561 \\
External Communication Convergence & 0.0989 & 0.0009 & 0.529 \\
\hline
\end{tabular}

6.3.4 Model Fit - Model III

Model III has run for Private Limited Bank only. The information below, for model fitness, reveals that overall model is significant at 5 percent level of significance with significance value of 0.000 hence can proceed with further interpretation.

Table 19. Model Fit - Model III

Model Fit

Chi-square

674.416

Degrees of freedom

164

Probability level

0.000

6.3.5 Coefficient Matrix

Coefficient matrix table clearly reveals that there is only significant impact of external communication convergence on brand understanding with significance value of 0.000 while rest of correlations have found insignificant at even 10 percent level of significance.

Table 20. Coefficient Matrix - Model III

\begin{tabular}{lllll}
\hline Coefficient Matrix & Estimate & S.E. & C.R. & P \\
\hline Brand Understanding <--- External Communication Convergence & 1.257 & 0.338 & 3.715 & 0.000 \\
Brand Commitment <--- External Communication Convergence & 0.07 & 0.177 & 0.395 & 0.693 \\
Brand commitment <--- Brand Understanding & -0.017 & 0.043 & -0.386 & 0.700 \\
Brand Citizenship Behavior <--- Brand Understanding & -2.056 & 15.72 & -0.131 & 0.896 \\
Brand Citizenship Behavior <--- External Communication & & & & \\
Convergence & 9.737 & 63.76 & 0.153 & 0.897 \\
Brand Citizenship Behavior <--- Brand Commitment & 0.013 & 0.073 & 0.178 & 0.859 \\
\hline $6.4 H y 07$
\end{tabular}

6.4 Hypotheses Assessment

Hypotheses testing and summaries below reveals that Hypotheses testing and summaries below reveals that hypotheses $\mathrm{H} 4$ is only in case of Private Limited Bank while rest of hypothesis got rejected. In contrast, in case of Biscuits Manufacturing Company hypotheses H4, H2 and H3 got accepted while rest has got rejected. Finally. in case of overall model hypotheses H4, H2 and $\mathrm{H} 3$ got accepted while rest got rejected.

\section{Discussion}

\subsection{Overall Model}

Overall model revealed that it followed with requirement of convergent and discriminate validity as KMO value found significant at 5 percent level of significance with value of 0.684 i.e. higher than 0.4. Furthermore, data has found not normally distributed with significance value less than 0.05 for all questions. It is due sample size issues. Furthermore, all sections of questions have found following requirement of reliability i.e. Cronbach's Alpha. In addition, factor loading values for all items of each variable have found higher than 0.7 hence support relevance of selected question to each section except a few. In addition, model fit results have also found significant at 5 percent level of significance with significance value of 0.000 .

Most importantly, it has found through this study that there is significant impact of external communication in determination of brand understanding with coefficient value of 1.257 and standard deviation of 0.338 hence reveal its positive influence on brand understanding. In contrast, rest of the factors have found with no significant impact on brand commitment and brand citizenship behavior at even 10 percent level of significance. Mahnert \& Torres (2007) 
also found significant role of external communication in determination of brand understanding with an explanatory tool toward targeted audience to understand the message and its positive influence on brand presence among employees.

Table 21. Coefficient Matrix (p values)

\begin{tabular}{llll}
\hline Hypotheses Testing & Mode III & Mode II & Mode I \\
\hline Brand Understanding <--- External Communication Convergence H4 & 0 & 0.001 & 0 \\
Brand Commitment <--- External Communication Convergence H5 & 0.693 & 0.749 & 0.585 \\
Brand commitment <--- Brand Understanding H2 & 0.7 & 0 & 0 \\
Brand Citizenship Behavior <--- Brand Understanding H3 & 0.896 & 0.004 & 0 \\
Brand Citizenship Behavior <--- External Communication Convergence H6 & 0.897 & 0.128 & 0.323 \\
Brand Citizenship Behavior <--- Brand Commitment H1 & 0.859 & 0.859 & 0.517 \\
\hline
\end{tabular}

7.1.1 Private Limited Bank

Model I for Private Limited Bank also clearly revealed that value of KMO is also higher for Private Limited Bank hence reveal its significance to support convergent and discriminate validity. Furthermore, reliability value has also found significant with value higher than benchmark value of 0.6 i.e. 0.930 . In addition, normality values have also found supportive in favor of non-normality with significance value less than 0.05 . In addition, Cronbach's Alpha values have also found favorable in support of different sections i.e. brand commitment, brand understanding, brand citizenship behavior and external communication convergence with value higher than 0.6 therefore justify reliability scale. In addition, significance value has also found with significance value of 0.000 less than 0.05 hence also support the acceptance of the model.

Coefficient matrix for Private Limited Bank also revealed that there is a significant impact of external communication on brand understanding with significance value of 0.00 and coefficient value of 1.11 hence reflect positive influence of external communication on brand understanding. Furthermore, brand understanding has also found significant role in determination of brand commitment with significance value of 0.000 and coefficient value of 0.336 hence reflect its deterministic power positively. Finally, brand understanding has also found with positive influence on brand citizenship behavior with coefficient value of 0.709 and significance value of 0.000 . Burmann et al, (2009) revealed through study that there is significant role of external communication in determination of brand understanding to express clearance of message to employee with its positive role in determination of their behavior toward employee's responsiveness. Morhart et al (2009) also revealed through study that there is positive contribution of brand understanding over brand commitment and brand citizenship behavior in positive manner to align employee behavior with incremental change in level of brand commitment and brand citizenship behavior among employees.

\subsubsection{Biscuits Manufacturing Company}

Model II for Biscuits Manufacturing Company also clearly elaborated that overall model II has significant value of significance i.e. less than 0.000 to supportive convergence and decrement validity with value of KMO of 0.887 . In addition, value of reliability is also higher than 0.6 i.e. 0.940 hence also support evidence in favor. Normality results are also found in favor of non-normality with significance value of less than 0.000 for each question. Furthermore, Cronbach's Alpha value has also found with value greater than 0.6 hence support reliability test also for each section of questionnaire in favor of Biscuits Manufacturing Company. In addition, factor loading values, at majority, also found supportive in favor of Biscuits Manufacturing Company hence support findings with selection of relevant questions. Model Fit has also found supportive to give evidence in favor of acceptance of model for Biscuits Manufacturing Company.

Coefficient matrix for Biscuits Manufacturing Company also reflected evidence in favor of Biscuits Manufacturing Company with significance value of 0.001 for external communication in determination of brand understanding with coefficient value of 1.013. It has reported with positive influence of external communication on brand commitment. Similarly, brand understanding has also found with positive influence on brand commitment and brand citizenship behavior with coefficient values of 0.77 and 0.425 respectively at 5 percent level of significance. It has also found through sequence of studies with positive influence of brand understanding in determination of brand commitment and brand citizenship behavior positively (Thomson et al, 1999; Burmann et al, 2009).

\subsection{Comparative assessment}

The comparative assessment of Private Limited Bank to Biscuits Manufacturing Company reveals that there is significant impact of external communication in determination of brand understanding in case of both firm but it has evident that coefficient power for Private Limited Bank is more evident as compare to Biscuits Manufacturing 
Company with coefficient values of 1.11 and 1.01 respectively. Furthermore, it has also found that there is significant impact of brand understanding in determination of brand commitment in case of both firm but it has evident that coefficient power for Private Limited Bank is less evident as compare to Biscuits Manufacturing Company with coefficient values of 0.336 and 0.77 respectively. In addition, it has also revealed that there is significant impact of brand understanding in determination of brand citizenship behavior in case of both firm but it has evident that coefficient power for Private Limited Bank is more evident as compare to Biscuits Manufacturing Company with coefficient values of 0.709 and 0.425 respectively. This comparative assessment clearly reflected importance of external communication and brand understanding in determination of brand understanding and brand citizenship behavior respectively while brand understanding role in determination of brand commitment is in favor of Biscuits Manufacturing Company.

\subsection{Theoretical Contribution}

This study has also supported to validate theoretical evidences of internal brand management practices with its conceptualization in case of selected firms. It has revealed that there is unidimensional behavior of brand commitment that has also justified the findings of previously conducted studies (Meyer \& Allen, 1990). In addition, three different aspect of organization commitment has also revealed through this study as observed in previously conducted studies in the form of brand citizenship behavior (Xiong et al. 2013; Piehler et al. 2016).

\section{Conclusion}

\subsection{Conclusion}

This study has performed with objective to determine the role of brand understanding, brand commitment and external communication convergence in determination of brand citizenship behavior along with role of external communication convergence as mediator to brand understanding and commitment also. Furthermore, role of brand understanding to brand commitment has also investigated. This study used CFA and SEM approach to investigate the phenomenon targeting on manufacturing firm and service firm. In addition, convince sampling design has adopted with equal sample weightage but encountered with 165 response collection from Private Limited Bank and 135 from Biscuits Manufacturing Company respectively. SPSS and AMOS software are used and results are extracted to test hypotheses. It has revealed through this study that there is significant role of external communication convergence in determination of brand understanding, branding understanding to brand commitment and brand understanding to brand citizenship behavior. It reflected mediating role of external communication convergence on brand citizenship behavior instead of direct impact.

\subsection{Implications}

This study clearly elaborated the importance of external communication in determination of brand understanding with its practices implication in uplifting employee moral toward the brand as evident in case of Private Limited Bank and Biscuits Manufacturing Company. In addition, importance of brand understanding has also found reported in case of brand commitment and brand citizenship behavior with its positive implications. This study also reported that external communication is an influential factor to affect brand internal management practices.

\subsection{Recommendations}

This study revealed importance of external communication in determination of brand understanding and later on explanatory power of brand understanding in determination of brand commitment and brand citizenship behavior. These areas can be improved in following manners. It is required to standardized and simplify external communication for manufacturing and service sector firms as found in case of Private Limited Bank and Biscuits Manufacturing Company respectively with immediate actions. In addition, it is also required to make attentive real scope of brand understanding with its implications on brand citizenship behavior and brand commitment. It is also required to periodically assess employee attitude toward brand understanding to understand channelization toward brand commitment and brand citizenship behavior.

\subsection{Prospects for Future Research}

To use this important subject in exploring industrial practices, this study only investigated two specific firms that can be extended to two specific industries of Pakistan.

\section{Reference}

Acito, F., \& Ford, J. D. (1980). How advertising affects employees. Business Horizons, 23(1), 53-59. https://doi.org/10.1016/0007-6813(80)90111-1

Allen, N. J., \& Meyer, J. P. (1990). The measurement and antecedents of affective, continuance and normative commitment to the organization. Journal of Occupational Psychology, 63(1), 1-18. 
https://doi.org/10.1111/j.2044-8325.1990.tb00506.x

Aurand, T. W., Gorchels, L., \& Bishop, T. R. (2005). Human resource management's role in internal branding: An opportunity for cross-functional brand message synergy. Journal of Product and Brand Management, 14(3), 163-169. https://doi.org/10.1108/10610420510601030

Baker, T. L., Rapp, A., Meyer, T., \& Mullins, R. (2014). The role of brand communications on front line service employee beliefs, behaviors, and performance. Journal of the Academy of Marketing Science, 42(6), 642-657. https://doi.org/10.1007/s11747-014-0376-7

Bandura, A. (1977). Social learning theory. Englewood Cliffs, NJ: Prentice Hall.

Baumgarth, C., \& Schmidt, M. (2010). How strong is the business-to-business brand in the workforce? An empirically-tested model of 'internal brand equity' in a business-to-business setting. Industrial Marketing Management, 39(8), 1250-1260. https://doi.org/10.1016/j.indmarman.2010.02.022

Bergstrom, A., Blumenthal, D., \& Crothers, S. (2002). Why internal branding matters: The case of Saab. Corporate Reputation Review, 5(2/3), 133-142. https://doi.org/10.1057/palgrave.crr.1540170

Berry, L. L. (1981). The employee as customer. Journal of Retail Banking, 3(1), 33-40.

Burmann, C., \& Zeplin, S. (2005). Building brand commitment: A behavioral approach to internal brand management. Journal of Brand Management, 12(4), 279-300. https://doi.org/10.1057/palgrave.bm.2540223

Burmann, C., Zeplin, S., \& Riley, N. (2009). Key determinants of internal brand management success: An exploratory empirical analysis. Journal of Brand Management, 16(4), 264-284. https://doi.org/10.1057/bm.2008.6

Celsi, M. F. W., \& Gilly, M. C. (2010). Employees as internal audience: How advertising affects employees' customer focus. Journal of the Academy of Marketing Science, 38(4), 520-529. https://doi.org/10.1007/s11747-009-0173-x

Chang, A., Chiang, H. H., \& Han, T. S. (2012). A multilevel investigation of relationships among brand-centered HRM, brand psychological ownership, brand citizenship behaviors, and customer satisfaction. European Journal of Marketing, 46(5), 626-662. https://doi.org/10.1108/03090561211212458

De Chernatony, L., Cottam, S., \& Segal-Horn, S. (2006). Communicating services brands' values internally and externally. Service Industries Journal, 26(8), 819-836. https://doi.org/10.1080/02642060601011616

De Chernatony, L., Drury, S., \& Segal-Horn, S. (2003). Building a services brand: Stages, people and orientations. Service Industries Journal, 23(3), 1-21. https://doi.org/10.1080/714005116

Dean, D., Arroyo-Gamez, R. E., Punjaisri, K., \& Pich, C. (2016). Internal brand co-creation: The experiential brand meaning cycle in higher education. Journal of Business Research, 69(8), 3041-3048. https://doi.org/10.1016/j.jbusres.2016.01.019

Delgado-Ballester, E., Munuera-Aleman, J. L., \& Yague-Guillen, M. J. (2003). Development and validation of a brand trust scale. International Journal of Market Research, 45(1), 35-53.

Diamantopoulos, A., \& Winklhofer, H. M. (2001). Index construction with formative indicators: An alternative to scale development. Journal of Marketing Research, 38(2), 269-277. https://doi.org/10.1509/jmkr.38.2.269.18845

Eatough, E. M., Chang, C. H., Miloslavic, S. A., \& Johnson, R. E. (2011). Relationships of role stressors with organizational citizenship behavior: A meta-analysis. Journal of Applied Psychology, 96(3), 619-632. https://doi.org/10.1037/a0021887

Fornell, C., \& Larcker, D. F. (1981). Evaluating structural equations models with unobservable variables and measurement error. Journal of Marketing Research, 18(1), 39-50. https://doi.org/10.1177/002224378101800104

George, W. R., \& Berry, L. L. (1981). Guidelines for the advertising of services. Business Horizons, 24(4), 52-56. https://doi.org/10.1016/0007-6813(81)90056-2

Gilly, M. C., \& Wolfinbarger, M. F. (1992). Does advertising affect your nurses? Journal of Health Care Marketing, 12(3), 24-31.

Hair, J. F., Ringle, C. M., \& Sarstedt, M. (2011). PLS-SEM: Indeed a silver bullet. Journal of Marketing Theory and Practice, 19(2), 139-151. https://doi.org/10.2753/MTP1069-6679190202

Hair, J. F., Sarstedt, M., Ringle, C. M., \& Mena, J. A. (2012). An assessment of the use of partial least squares structural equation modeling in marketing research. Journal of the Academy of Marketing Science, 40(3), 414-433. https://doi.org/10.1007/s11747-011-0261-6 
Hair, J. F., Sarstedt, M., Ringle, C. M., \& Gudergan, S. P. (2018). Advanced issues in partial least squares structural equation modeling (PLS-SEM). Thousand Oaks, CA: Sage.

Harris, F., \& De Chernatony, L. (2001). Corporate branding and corporate brand performance. European Journal of Marketing, 35(3/4), 441-456. https://doi.org/10.1108/03090560110382101

Henkel, S., Tomczak, T., Heitmann, M., \& Herrmann, A. (2007). Managing brand consistent employee behaviour: Relevance and managerial control of behavioral branding. Journal of Product and Brand Management, 16(5), 310-320. https://doi.org/10.1108/10610420710779609

Hughes, D. E. (2013). This ads for you: The indirect effect of advertising perceptions on salesperson effort and performance. Journal of the Academy of Marketing Science, 41(1), 1-18. https://doi.org/10.1007/s11747-011-0293-y

Ind, N. (2001). Living the brand: How to transform every member of your organization into a brand champion. London: Kogan Page.

Jarvis, C. B., Mackenzie, S. B., \& Podsakoff, P. M. (2003). A critical review of construct indicators and measurement model misspecification in marketing and consumer research. Journal of Consumer Research, 30(2), 199-218. https://doi.org/10.1086/376806

Kahn, R. L., Wolfe, D. M., Quinn, R. P., Snoek, J. D., \& Rosenthal, R. A. (1964). Organizational stress: Studies in role conflict and ambiguity. New York, NY: Wiley.

Piehler, R., Baron, R. M., \& Kenny, D. A. (1986). The moderator-mediator variable distinction in social psychological research: Conceptual, strategic, and statistical considerations. Journal of Personality and Social Psychology, 51(6), 1173-1182. https://doi.org/10.1037/0022-3514.51.6.1173

\section{Copyrights}

Copyright for this article is retained by the author(s), with first publication rights granted to the journal.

This is an open-access article distributed under the terms and conditions of the Creative Commons Attribution license which permits unrestricted use, distribution, and reproduction in any medium, provided the original work is properly cited. 